\author{
Edyta Sygut \\ University of Economics in Katowice \\ e-mail: edyta.sygut@ue.katowice.pl \\ ORCID: 0000-0002-3644-0505
}

\title{
FISCAL EFFICIENCY OF EXCISE DUTY ON PASSENGER CARS IN POLAND
}

\section{WYDAJNOŚĆ FISKALNA PODATKUAKCYZOWEGO OD SAMOCHODÓW OSOBOWYCH W POLSCE}

DOI: $10.15611 / \mathrm{pn} .2019 .5 .07$

JEL Classification: H23, H21, H30

\begin{abstract}
Summary: Excise duty is a harmonised tax within the EU; however, EU law does not govern the imposition of excise duty on passenger cars. EU Member States were granted the right to tax non-harmonised products or services and the freedom to shape such regulations. The purpose of this article is to state the reasons why excise duty is imposed on passenger cars, as well as to analyse and assess the fiscal efficiency of the imposition of excise duty on passenger cars in Poland. The analysis covered the budget revenue from excise duty on passenger cars in 2009-2017. The conclusion is that the reason of the imposition of excise duty on passenger cars in Poland is mainly the implementation of the fiscal function. The excise duty revenue on passenger cars is a stable source of budget revenue; however, its importance in the total excise duty revenue structure is only supplementary. The revenue related to the Intra-Community acquisition of passenger cars to Poland has a dominant share in this structure.
\end{abstract}

Keywords: excise duty, passenger car, luxury good, environmental tax, fiscal efficiency.

Streszczenie: Podatek akcyzowy jest podatkiem zharmonizowanym na terenie UE, jednak prawo unijne nie reguluje opodatkowania akcyzą samochodów osobowych. Państwom członkowskim UE pozostawiono prawo do opodatkowania wyrobów lub usług nieobjętych harmonizacją i swobodę w kształtowaniu tych regulacji. Celem artykułu było wskazanie przyczyn opodatkowania akcyzą samochodów osobowych, a także analiza i ocena wydajności fiskalnej opodatkowania akcyzą samochodów osobowych w Polsce. Analizą objęto dochody budżetowe z podatku akcyzowego na samochody osobowe w latach 2009-2017. Stwierdzono, że przyczyną opodatkowania akcyzą samochodów osobowych w Polsce jest przede wszystkim realizacja funkcji fiskalnej. Dochody z podatku akcyzowego od samochodów osobowych stanowią stabilne źródło dochodów budżetowych, jednak w strukturze dochodów z podatku akcyzowego ogółem mają znaczenie jedynie uzupełniające. Dominujące znaczenie mają dochody związane z wewnątrzwspólnotowym nabyciem samochodów osobowych do Polski.

Słowa kluczowe: podatek akcyzowy, samochód osobowy, dobro luksusowe, podatek ekologiczny, wydajność fiskalna. 


\section{Introduction}

The essence of excise duty is the selective taxation of strictly defined product groups. Among these products, particular attention should be drawn to passenger cars. Excise duty is a harmonised tax within the European Union, however EU law does not govern the imposition of excise duty on passenger cars. Without prejudice to the harmonisation process of excise duty, pursuant to Art. 1 Par. 3, the Member States retained the right to impose excise duty on other goods than harmonised goods and on the supply of services [Council Directive 2008/118/EC]. However, taxation cannot cause any further formalities in trade exchange between the Member States related to the crossing of borders [Paragraph 5 of the Preamble to Council Directive 2008/118/EC]. Directive 2008/118/EC does not require the imposition of a tax on nonharmonised goods or on the supply of services to be justified by the implementation of a specific purpose [Terra, Wattel 2012, p. 469]. Using the right to impose excise duty on other goods than harmonised goods, Poland and certain other EU Member States impose taxes on passenger cars [ACEA Tax Guide 2018, p. 6]. For example, excise duty on passenger cars is in effect in Croatia [www1] and Cyprus [www2].

The purpose of this article is to indicate the reasons why excise duty is imposed on passenger cars, as well as to analyse and assess the fiscal efficiency of the imposition of excise duty on passenger cars in Poland. The analysis covered the budget revenue from excise duty on passenger cars in 2009-2017.

\section{Reasons for passenger car taxation}

One of the fundamental theoretical features of excise duty is its selective nature. The source literature indicates that the goods that are subject to excise duty may belong to one of the following three groups of goods: basic consumer goods, expendable goods or luxury goods. The specific nature of this tax does not exclude the possibility of the taxation of services, in practice however, it is specific goods that are subject to taxation. The choice of goods that are subject to excise duty may be justified in many different ways. The causes of passenger car taxation may be connected with the implementation of both the fiscal and non-fiscal functions by this tax. First of all, the reason for the imposition of excise duty on passenger cars is the willingness to implement the fiscal function, which is imposed on every tax. The fiscal function is connected with gathering the funds necessary to finance public services. In this context, fiscal efficiency is understood as the ability to achieve revenue as a result of taxation. The universal consumption of this good should be a guarantee of relatively regular and high budget revenue [Famulska 2007, p. 16]. In theory, the imposition of excise duty on passenger cars should be characterised by high fiscal efficiency due to the universal consumption of this good and the lack of satisfactory substitutes on the market. The fiscal efficiency of excise duty on passenger cars will be analysed in the further part of this article. 
Another reason for the imposition of excise duty on particular goods is the possibility to implement non-fiscal functions by influencing the consumption of goods that fulfil specific types of needs, or have adverse external effects in the social, health or environmental area. The use of passenger cars for fast transport has negative external effects, e.g. exhaust emission and noise. Excise duty may be used for the internalisation of external costs, i.e. to increase the costs incurred by consumers in order to cover the total social cost in cases when the price of a specific good does not include the total social costs connected with its use [McGee 2014, pp. 232-233]. The reduction of the negative external effects related to the consumption of specific goods consists in lowering the demand by influencing the price of goods [Atkinson et al. 1996, p. 25]. In the case of passenger car taxation, excise duty should perform the function of an environmental tax. Environmental taxes consist in adding environmental surcharge to the prices of products that are harmful to the environment [Kryk, Kłos, Łucka 2011, p. 27]. According to the classification applied by Eurostat, four groups of environmental taxes are distinguished. The criterion used for this division was the subject of taxation, therefore the following groups were proposed: energy taxes, transport taxes, emission taxes and natural resource taxes [www3]. Excise duty on passenger cars should be considered among the group of transport taxes, which includes taxes related mainly to the use of motor vehicles.

The use of environmental taxes allows to adapt tax systems to achieve proenvironmental goals. The structure of environmental taxes, especially tax rates, should help achieve regular budget revenue while simultaneously stimulating its impact. The changes introduced recently by the public authorities in respect of exemptions from excise duty on passenger cars in Poland indicate that this tax is to act as an environmental tax, stimulating pro-environmental behaviours.

Moreover, the reason for imposing excise duty is the willingness to improve the progressivity of the tax system in a specific country [Cnossen (ed.) 2005, p. 6]. The imposition of excise duty on passenger cars to improve the progressivity of the tax system is based on the assumption that passenger cars are luxury goods. This view, taking into consideration the importance of passenger cars in the current reality and the existing structure of excise duty on passenger cars in Poland, is definitely controversial.

The term 'luxury goods' is hard to define due to its nature, which is relatively subjective and variable over time and space. The term 'luxury' is defined as 1 . «expensive and beautiful thing providing comfortable life» 2. «expensive thing, which is nice to have, but not necessary» 3. «a pleasure that one can rarely afford» [www4].

Luxury goods are frequently defined through their distinctive features, which include great quality, very high price, rarity, unique aesthetics and expendability, i.e. the fact that a particular good is not necessary for existence [Kapferer et al. 2017].

Taking into consideration these features, a passenger car should be considered as a basic consumer good. The need for transport, broadly understood as the movement 
of persons and property, is one of the basic needs related to the activity of natural persons in the private sphere (e.g. travel to work, holiday trips). A passenger car allows to fulfil this need in a relatively quick and safe manner. Moreover, a passenger car is an inherent and frequently necessary tool used by natural persons for their business activity (transport services, services provided on-site or directly at the customer's premises). What is more, a passenger car is a good available for a considerable part of society. The prices of passenger cars are very different, which means that it is available only for the richest individuals. Possession of a passenger car (without taking into consideration its detailed technical specification) is no longer a sign of luxury.

In light of the presented arguments, the imposition of excise duty on passenger cars in order to improve the progressivity of the tax system, and thus consider it as a luxury good, would require to formulate additional criteria for excise duty, allowing to recognise its luxurious nature. This criterion could be judgmental. Exceeding the car's value limit by the legislator would result in classifying a particular car as a luxury good under the tax law, and as a consequence, in imposing excise duty or a higher tax rate.

\section{Elements of excise duty structure affecting its fiscal efficiency}

\subsection{The objective and subjective scope of taxation}

The essential thing about the imposition of excise duty on passenger cars is to define the term 'passenger cars'. The statutory definition of passenger cars created for the purpose of the imposition of excise duty refers to Combined Nomenclature. Pursuant to Art. 100 Par. 4, passenger cars are motor cars and other motor vehicles of heading 8703, principally designed for the transport of persons (other than those of heading 8702), including station wagons and racing cars, with the exception of motor cars and other motor vehicles which do not require registration in accordance with the road traffic regulations [Act of 6 December 2008]. Consequently, the following two conditions must be met jointly in order to determine whether a particular car is subject to excise duty: the car is of heading CN 8703 (which confirms its 'passenger' nature) and it must be registered in accordance with the road traffic regulations. The obligation of correct car classification in accordance with the Combined Nomenclature lies with the manufacturer, the person making the Intra-Community acquisition, or the importer. As of 1 January 2015, taxpayers in Poland were provided with the possibility to use the institution of binding excise information, i.e. an individual decision issued by the tax authorities for the purpose of the imposition of excise duty, e.g. on passenger cars. This enables to obtain information on classification according to Combined Nomenclature $(\mathrm{CN})$ of a particular motor car or other product.

Moreover, the determination of the objective scope also requires to specify the events that are subject to excise duty. In the case of passenger cars, these include: 
- the import of a passenger car previously unregistered in the country;

- the Intra-Community acquisition of a passenger car previously unregistered in the country;

- the first sale in the territory of the country of a passenger car previously unregistered in the country (e.g. manufactured in the country or imported to the country, for which the excise duty was not paid).

The payer of excise duty on passenger cars was defined very briefly. The legislator has specified natural persons, legal entities and organisational units without a legal personality that carry out taxable transactions.

\subsection{Tax base and tax rates}

The detailed rules of imposition of excise duty on passenger cars in Poland are also reflected in the structure of the tax base and tax rates. As a principle, the tax base for the imposition of excise duty is expressed quantitatively, i.e. with the measurement unit that corresponds to the specific nature of a particular excise good (e.g. kg, hl), consequently specific rates are applied. ${ }^{1}$ On the other hand, in the case of passenger cars, the tax base was expressed in value, and therefore, ad valorem rates are applied (see Table 1).

Table 1. Tax base and rates of excise duty on passenger cars in Poland

\begin{tabular}{|l|r|l|}
\hline \multicolumn{1}{|c|}{ Product type } & Tax rate & \multicolumn{1}{c|}{ Tax base } \\
\hline $\begin{array}{l}\text { Passenger cars } \\
\text { with engine capacity } \\
\text { above 2,000 } \mathrm{cm}^{3}\end{array}$ & $18.6 \%$ & $\begin{array}{l}\text { amount due for sale less VAT and excise duty (in case of } \\
\text { sale in the country); } \\
\text { amount that the taxpayer is obliged to pay for passenger } \\
\text { car (in case of Intra-Community acquisition); } \\
\text { Other passenger cars }\end{array}$ \\
$\begin{array}{l}\text { customs value of the car plus duty payable (in case of } \\
\text { import). }\end{array}$
\end{tabular}

Source: own study based on the Act of 6 December 2008 on excise duty, uniform text of the Journal of Laws of 2018, Item 1114 with further amendments.

In order to calculate the tax base expressed in a foreign currency, the current average exchange rate of this currency calculated and published by the National Bank of Poland on the date when the tax obligation arises is used. This applies for the import and Intra-Community acquisition of passenger cars to Poland.

Since 1 January 2009 the legislator has specified two rates of excise duty on passenger cars, depending only on the engine capacity. Due to such a structure of the tax base and tax rates in excise duty on passenger cars, this tax does not act as an environmental tax in Poland. The excise duty rate in Poland does not include the

${ }^{1}$ Exceptions include cigarettes and smoking tobacco, for which the rates are mixed (amount and percentage). 
environmental effects. For example this is different in the Netherlands, where the specific rates of tax on passenger cars are applied and their amount depends on the type of fuel (there are separate rates for petrol and diesel-fuelled passenger cars) and $\mathrm{CO}_{2}$ emission [www5].

Passenger cars are the main source of $\mathrm{CO}_{2}$ emission, thus being particularly important in respect of environmental protection. The countries that impose taxes on passenger cars partly or wholly based on $\mathrm{CO}_{2}$ emission or fuel consumption include: Austria, Belgium, Croatia, Cyprus, Denmark, Finland, France, Germany, Greece, Ireland, Latvia, Luxembourg, Malta, The Netherlands, Portugal, Romania, Slovenia, Spain, Sweden and the United Kingdom [www6]. On the other hand, Bulgaria, Estonia, Italy and Lithuania, like Poland, do not include $\mathrm{CO}_{2}$ emission in passenger car taxation [www5]. The lack of uniformity in the imposition of these taxes was the basis for the European Commission to submit a proposal concerning the Council Directive on passenger car related taxes. Its goal was to improve the functioning of the internal market and develop the Community's strategy to reduce $\mathrm{CO}_{2}$ emissions from passenger cars [www7]. The main assumption of this Directive was to introduce the $\mathrm{CO}_{2}$ component in the tax base of annual circulation taxes and registration taxes [www8]. After the unsuccessful negotiations between EU Member States in the Council, the proposal was withdrawn by the EC in 2015.

\subsection{Tax exemptions}

Tax exemption is an element of the tax structure that significantly affects its fiscal efficiency. The excise duty legislation also provides for a number of excise duty exemptions for passenger car-related activities.

Provisions of the Act lay down the rules for excise duty exemption of passenger cars imported to Poland by individuals arriving in Poland for permanent residence (Art. 110) or temporary residence (Art. 111) from EU Member States or EFTA Member States, as well as from outside the territory of these states (Art. 112) [Act of 6 December 2008]. Moreover, pursuant to Art. 110, excise duty exemption shall apply to passenger cars imported to Poland by individuals arriving in Poland for permanent residence on the occasion of marriage, or in cases when they acquired the right to own or use a passenger car by inheritance in the territory of a Member State. An interesting fact is that these exemptions result from the provisions of Community law and are mandatory. The provisions of Council Directive 2009/55/ $\mathrm{EC}^{2}$ are intended to improve the uniform market, in particular to avoid the double taxation of passenger cars when citizens move from one Member State to another and to remove obstacles to cross-border passenger car rental.

Particular attention should also be drawn to excise duty exemption for electric or hydrogen-fuelled passenger cars [Act of 6 December 2008]. Tax preferences are

\footnotetext{
${ }^{2}$ Directive 2009/55/EC replaced Directive 83/183/EEC and constitutes its consolidated text.
} 
an important tool for the development of demand for low-emission passenger cars. Croatia, Estonia and Lithuania are currently the only Member States which do not apply any tax preferences for electric vehicles (not just passenger cars). [www8]. In Poland, this exemption shall be considered as an attempt to impose the function of environmental tax on excise duty. However, the implementation of this preference required the European Commission to confirm that these regulations do not constitute state aid. On 18 December 2018, the European Commission decided that excise duty exemption for electric and hydrogen-fuelled passenger cars does not constitute state aid and can be applied in the national law. This means that the above-indicated tax preference can be used, provided that the excise duty obligation arose after the European Commission expressed its position, i.e. starting from 19 December 2018.

\section{Analysis of the fiscal efficiency of passenger car taxation in 2009-2017}

In Poland, all excise duty revenue supports the state budget. Its share in budget revenue is relatively stable and unchanging - approximately 20\% [Sygut 2015, p. 335], which reflects the high fiscal efficiency of this tax. The analysis of fiscal efficiency of the imposition of excise duty on passenger cars in 2009-2017 covers the volume of revenue, dynamics, share in total excise duty revenue, as well as the structure of revenue and the fiscal consequences of preferential passenger car taxation (see Tables 2 and 3). It should be emphasized that the legal regulations concerning the structure of excise duty on passenger cars did not change substantially in the analysed period.

In 2009-2017, the volume of excise duty revenue on passenger cars, similarly to the total excise duty revenue, was characterised by a steady-growth trend. The excise duty revenue on passenger cars increased by $67 \%$, i.e. from PLN million $1,530.2$ in 2009 to PLN million 2,548.6 in 2017 (see Table 2). This is confirmed by the dynamics of excise duty revenue on passenger cars, which grew on average by $10 \%$ in comparison with the previous year. In the analysed period, the excise duty revenue on passenger cars should be considered as a significant source of budget revenue.

The selective nature of the imposition of excise duty results in the different fiscal efficiency of taxation in specific groups of excise goods. The excise duty revenue on passenger cars in comparison with the total excise duty revenue in the analysed period is $2.8 \%$ on average. This means that, compared to other excise goods, the significance of passenger car taxation is purely supplementary.

In the context of the fiscal efficiency of excise duty on passenger cars, is the structure of tax revenue that includes the type of event under which the tax obligation arises (Intra-Community acquisition, country, import) is interesting. In the analysed period, the highest total excise duty revenue is related to domestic activities. The structure of excise duty revenue on passenger cars is formed completely differently, because the revenue on domestic activities constitutes only $2 \%$ on average. Although 


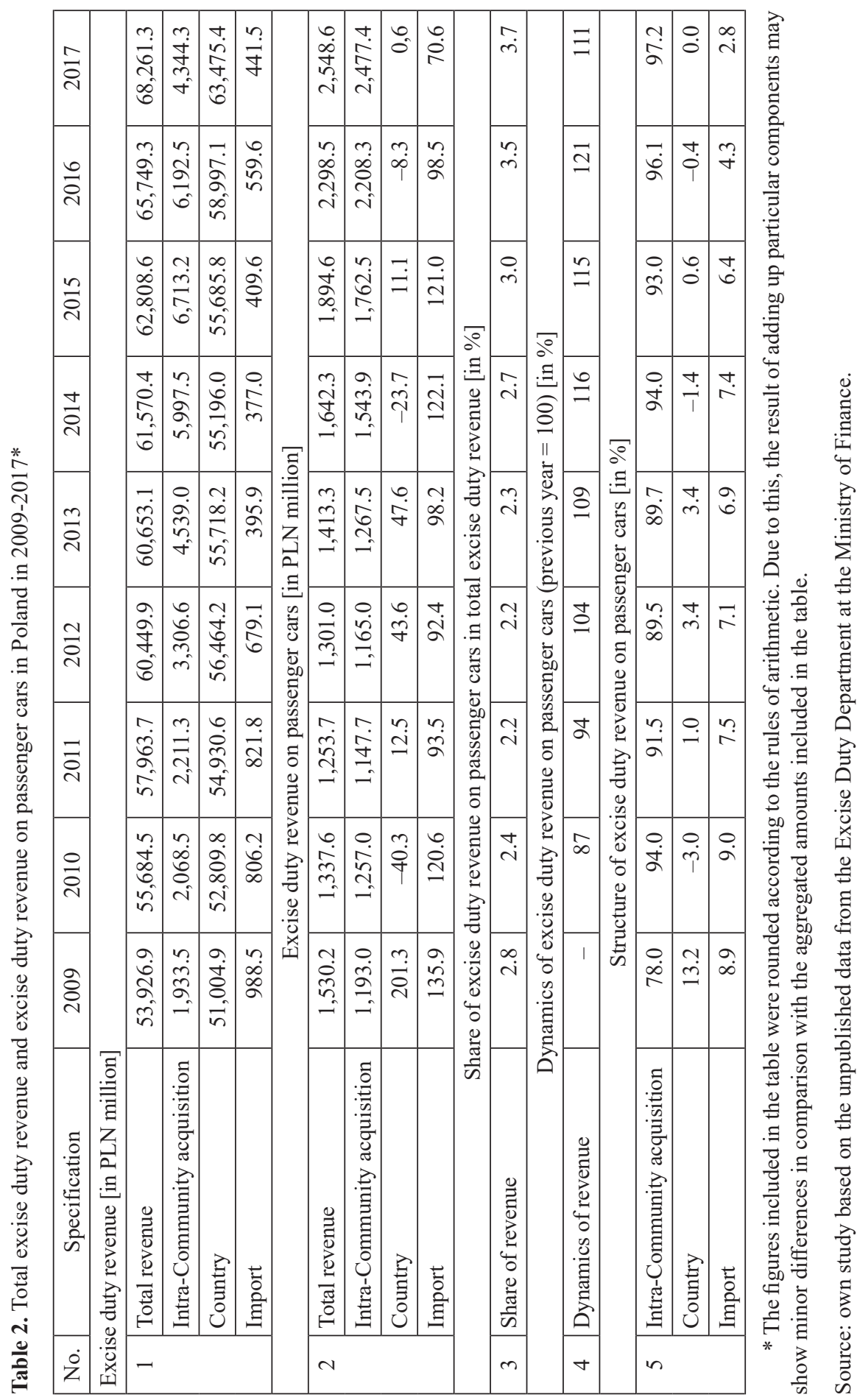


the domestic trade of passenger cars is usually large, the first registration of a passenger car in the territory of Poland is the sole circumstance under which the tax obligation arises. This results from the fact that excise duty is a single-phase tax, i.e. an excise good should be taxed only once. This means that only the purchase of a new car brings revenue to the budget in the domestic trade. Consequently, domestic transactions are of marginal importance in the structure of excise duty revenue.

What is more, the taxation of domestic activities related to passenger cars in 2010,2014 and 2016 resulted in a negative budget revenue. This situation is the effect of the right to apply for the refund of excise duty paid during the Intra-Community delivery and the export of passenger cars against which the excise duty was paid in the territory of the country pursuant to Art. 107 Par. 1 [Act of 6 December 2008]. The revenue related to the Intra-Community acquisition of passenger cars to Poland has a largely dominant share in the structure. Its share in the excise duty revenue on passenger cars in 2009-2017 was $91 \%$ on average, whereas the revenue on taxing the import of passenger cars to Poland in the analysed period was $7 \%$ on average.

The analysis of the fiscal efficiency of the imposition of excise duty on passenger cars in Poland requires including the budget revenue lost as a result of applying tax preferences for passenger cars (see Table 3). This is a difficult task because the specific nature of the tax exemptions used limits the possibility to estimate tax expenditures. Since 2012 the Ministry of Finance has been monitoring the amounts of lost revenue related to the preferential taxation on passenger cars in Poland as a result of applying mandatory tax exemptions based on EU law set out in Art. 110 and Art. 112 [Act of 6 December 2008].

Table 3. Volume of tax expenditures due to the application of selected tax exemptions concerning excise duty on passenger cars and their impact on the fiscal efficiency of excise duty in Poland in 2012-2017

\begin{tabular}{|l|c|c|c|c|c|c|}
\hline \multicolumn{1}{|c|}{ Specification } & 2012 & 2013 & 2014 & 2015 & 2016 & 2017 \\
\hline $\begin{array}{l}\text { Tax exemption amount resulting } \\
\text { from Art. 110 [in PLN million] }\end{array}$ & 4.75 & 4.21 & 6.29 & 5.98 & 7.20 & 4.57 \\
\hline $\begin{array}{l}\text { Tax exemption amount resulting } \\
\text { from Art. 112 [in PLN million] }\end{array}$ & 11.05 & 9.02 & 12.05 & 16.53 & 8.48 & 11.01 \\
\hline $\begin{array}{l}\text { Share of tax exemptions under Art. 110 } \\
\text { in excise duty revenue on passenger cars [in \%] }\end{array}$ & 0.37 & 0.30 & 0.38 & 0.32 & 0.31 & 0.18 \\
\hline $\begin{array}{l}\text { Share of tax exemptions under Art. 112 } \\
\text { in excise duty revenue on passenger cars [in \%] }\end{array}$ & 0.85 & 0.69 & 0.93 & 1.27 & 0.65 & 0.85 \\
\hline $\begin{array}{l}\text { Total share of tax exemptions under Art. 110 } \\
\text { and Art. 112 in excise duty revenue on } \\
\text { passenger cars [in \%] }\end{array}$ & 1.21 & 0.99 & 1.31 & 1.59 & 0.96 & 1.03 \\
\hline
\end{tabular}

Source: own study based on the unpublished data from the Excise Duty Department at the Ministry of Finance. 
In 2012-2017 the volume of tax expenditures for the application of exemptions from tax on the imposition of excise duty on passenger cars in Poland was characterised by a steady growth tendency. The growth was even, except for 2015 when a sharp increase of tax expenditures was noted in connection with the application of excise duty exemption for passenger cars imported to Poland by individuals arriving in Poland from outside the territory of EU Member States or EFTA Member States (Art. 112).

However, despite the increase of tax expenditures related to the preferential taxation on passenger cars, a decrease of their share in excise duty revenue on passenger cars was noted, which means that their impact on the fiscal efficiency of the imposition of excise duty on passenger cars decreased. At the same time, a significantly bigger impact of the fiscal efficiency of passenger car taxation on the application of exemption defined in Art. 112 of the Act on Excise Duty was noted.

It should be concluded that the excise duty revenue on passenger cars in Poland is supplementary in the structure of excise duty revenue. However, the dynamic nature of this revenue leads to the conclusion that it is a stable source of budget revenue. On the other hand, the application of mandatory tax exemptions based on EU law reduces the budget revenue from excise duty on passenger cars in the analysed period by $1.2 \%$ on average, which should be considered as a significant loss of revenue.

\section{Conclusion}

Excise duty is a harmonised tax within the European Union, however not in respect of the imposition of excise duty on passenger cars. The EU Member States were granted the right to tax non-harmonised products or services, as well as the freedom to shape such regulations. Poland and other Member States are using this right to impose excise duty on passenger cars, among other products. Passenger cars in Poland have been subject to excise duty in Poland continuously since 1993.The reasons for passenger car taxation are connected with the implementation of both fiscal and non-fiscal functions by this tax.

The current structure of excise duty on passenger cars allows to conclude that excise duty on passenger cars acts as an environmental tax only to a limited extent. The tax base and rates of excise duty on passenger cars do not include the environmental effects. The introduction of excise duty exemption on electric and hydrogen-fuelled passenger cars in December 2018 should be considered as the first attempt to use this tax for achieving pro-environmental objectives and stimulating consumption. Moreover, the cause of passenger car taxation could be the willingness to improve the progressivity of the tax system. Passenger car taxation for this purpose is based on the assumption that a passenger car is a luxury good. However, neither the importance of passenger cars in the current reality nor the existing structure of excise 
duty in Poland, confirms this assumption. In such circumstances the conclusion is that passenger car taxation in Poland mainly performs the fiscal function.

In the analysed period, the excise duty revenue on passenger cars in comparison with the total excise duty revenue is $2.8 \%$ on average. This means that the excise duty revenue on passenger cars in the structure of excise duty revenue is only supplementary. However, its dynamic nature leads to the conclusion that it is a stable source of budget revenue.

The revenue related to the Intra-Community acquisition of passenger cars to Poland has a largely dominant share in the structure. Its share in the excise duty revenue on passenger cars in 2009-2017 was $91 \%$ on average, whereas the revenue on taxing the import of passenger cars to Poland in the analysed period was $7 \%$ on average. On the other hand, the revenue on domestic activities constitutes only $2 \%$ on average. Although the domestic trade of passenger cars is usually large, the first registration of a passenger car in the territory of Poland is the sole circumstance under which the tax obligation arises. This results from the fact that excise duty is a single-phase tax, i.e. an excise good should be taxed only once. This means that only the purchase of a new car brings revenue to the budget in the domestic trade. As a result, domestic transactions are of marginal importance in the structure of excise duty revenue.

It is difficult to assess the impact of the applied excise duty exemptions concerning passenger cars on the fiscal efficiency of the taxation of these products, because the specific nature of a significant part of these exemptions does not allow to monitor the loss of budget revenue. In 2009-2017 the Ministry of Finance monitored the fiscal consequences of the sole application of mandatory tax exemptions based on EU law in respect of passenger car taxation. Their application resulted in the reduction of budget revenue from excise duty on passenger cars in the analysed period by $1.2 \%$ on average, which should be considered as a significant loss of revenue.

\section{Bibliography}

ACEA Tax Guide 2018, European Automobile Manufacturers' Association, https://www.acea.be/publications/article/acea-tax-guide (26.02.2019).

Act of 25 October 1948 on turnover tax (Journal of Laws of 52, Item 413 with amendments).

Act of 6 December 2008 on Excise Duty, uniform text of Journal of Laws of 2018, Item 1114 with amendments.

Atkinson B., Baker P., Milward B., 1996, Economic Policy, Macmillan, Houndmills.

Cnossen S. (ed.), 2005, Theory and Practice of Excise Taxation. Smoking, Drinking, Gambling, Polluting and Driving, Oxford University Press, Oxford.

Council Directive 2008/118/EC of 16 December 2008 on the general arrangements for excise duty and repealing Directive 92/12/EEC, EU Official Journal L 9, p. 12.

Council Directive 2009/55/EC of 25 May 2009 on tax exemptions applicable to the permanent introduction from a Member State of the personal property of individuals, EU Official Journal L 145, p. 36 . 
Council Directive of 28 March 1983 on tax exemptions applicable to the permanent introduction from a Member State of the personal property of individuals, EU Official Journal L 105, p. 64.

Famulska T., 2007, Teoretyczne i praktyczne aspekty funkcjonowania podatku od wartości dodanej, Wydawnictwo Akademii Ekonomicznej w Katowicach, Katowice.

Kapferer J.-N., Kernstock J., Brexendorf T.O., Powell S.M., 2017, Advances in Luxury Brand Management, Springer International Publishing AG, Cham.

Kociak N., 2017, Historia akcyzy w Polsce. Czy nadal podatek od dóbr luksusowych?, Kortowski Przegląd Prawniczy, no. 1, pp. 112-117.

Kryk B., Kłos L., Łucka I.A., 2011, Opłaty i podatki ekologiczne, CeDeWu, Warszawa.

McGee R.W., 2014, The Philosophy of Taxation and Public Finance, Kluwer Academic Publishers, Boston.

Sygut E., 2015, Wydajność fiskalna a przedmiot i podstawa opodatkowania podatku akcyzowego, Prace Naukowe Uniwersytetu Ekonomicznego we Wrocławiu, no. 403, pp. 331-340.

Terra J.M., Wattel P.J., 2012, European Tax Law, Kluwer Law International, Alphen aan den Rijn.

[www1] https://carina.gov.hr/pristup-informacijama/propisi-i-sporazumi/trosarinsko-postupanje/visinei-nacin-obracuna-trosarina-posebnih-poreza/motorna-vozila/3633 (28.04.2019).

[www2] https://www.mof.gov.cy/mof/customs/customs.nsf/All/A2C3593B5465A799422577D6002FEAC4?OpenDocument (28.04.2019).

[www3] https://ec.europa.eu/eurostat/web/environment/environmental-taxes (20.02.2019).

[www4] https://dictionary.cambridge.org/dictionary/english/luxury (20.02.2019).

[www5]http://ec.europa.eu/taxation_customs/tedb/legacy/taxDetail.html;jsessionid=xOMprW61fy-TZ_y 7QW6AJB73BTFwr6x6JMpQ7K_Mhdf3DbAqBEOK!56043766?id=443/1388754879\&taxType$=$ Other\%20indirect $\% 20 \operatorname{tax}(26.02 . \overline{2} 019)$.

[www6] https://www.acea.be/publications/article/overview-of-co2-based-motor-vehicle-taxes-in-theeu (26.02.2019).

[www7] https://eur-lex.europa.eu/legal-content/PL/ALL/?uri=CELEX\%3A52005PC0261 (27.02.2019).

[www8] https://ec.europa.eu/taxation_customs/individuals/car-taxation/passenger-car-taxation_en (26.02.2019).

[www9] https://www.acea.be/publications/article/overview-of-incentives-for-buying-electric-vehicles (27.02.2019). 